sufficient detail to facilitate careful study of the political, legal and technical work of the various organs of the League of Nations. (Geneva: Iseague of Nations; London: Georgo Allen and Unwin, Ltd., 1939. Pp. 214. 1s.). Of special interest to scientific workers are the chapters on intellectual co-operation, the health organization, the communications and transit organization and those on the Furopean conference on rural life and technical collaboration with China. A chapter dealing with refugees is included as well as one on mandates. The detailed chronological tablo of the principal events in the Iscague's sphero of activity during the year, giving the dates of the meetings of the different organs of tho Leaguo and of their principal decisions, as well as of world political ovents affecting the I.eaguo's work introduced last year for the first time is again a feature of tho now edition.

\section{The Colonial Problem}

THe proposals of the I,abour and Peace movements for dealing with the colonial question aro examined in a pamphlet "Now Tendencies in Colonial Policy" issued by the Pacifist Research Bureau (New Tendencies in Colonial Policy. With an Introduction by Leonard Bames. Pp. 16. Iondon : Pacifist Research Bureau, 1939. 2d.). It is argued that there are only two alternatives: an extended and re. arranged imperialism with now rival imperialisms of greater cquality and an ultimate clash between them; or tho removal of existing imperialisms and their substitution by a great conception of civiliza. tion's responsibility for tho so-called uncivilized, with an equally great concoption of world economic organization. The necessity of conforming to tho wishes, or, at least, obtaining the consent of the native peoples in all matters affecting their welfare is also emplasized, including tho application of this principlo not only to the mandated territories but also in other colonial questions. The problem is further discussed in another pamphlet issued by the Bureau, "War and the Colonies" (War and the Colonies: a Policy for Socialists and Pacifists. PP. 16. Iondon : Pacifist Research Bureau, 1939. 2d.), in which proposals for a world conference to effect tho liquidation of imperialism are briefly outlined.

\section{Language in Science}

THE general considerations of linguistics which throw light upon the procedure of science are dis. cussed by $L$. Bloomfield in the fourth number of volume one of the "International Encyclopedia of Unified Science" (Linguistic Aspects of Science. By Leonard Bloomfield. Pp. viii +60 . (Chicago : University of Chicago Press; London : Cambridge University Press, 1939.) 5s. net.). If language is taken into account, science can bo distinguished from other phases of human activity by agreeing that science shall deal only with ovents that aro accessiblo in their timo and place to any and all observers or only with events that aro placed in co-ordinates of timo and space, or that science shall employ only such initial statements and pre. dictions as lead to definite handling operations or only terms such as aro derivablo by strict definition from a set of everyday terms concerning physical happenings.

IT is the task of science to provide a system of responses which are independent of the habits of any person or community, but Mr. Bloom. field points out how far short wo aro of accurate definition in regard to meanings which aro involved in the habits of communities and individuals, since the relevant branches of science are quite undeveloped. Discussing the development of scientific language, ho distinguishes between the informal and formal scientific discourse, and emphasizes the importance of defining exactly the meaning of technical terms and limiting their use within the agreements upon which they are based. When meanings of the outside world are admitted, error may be incurred and certainty is lost. With regard to the place of linguistics in the schemo of science Mr. Bloomfield places it between biology and ethnology, sociology and psychology. It stands between physical and cultural anthropology. It is closely rolated to logic, since it observes how people conduct a certain typo of discourse. The critique and theory of scientific speech is tho task of logic. Mathematics, howover, is a science only so long as wo believe that the mathematician is not creating speech-forms and discourses (which is a slill, craft, or art) but exploring an unknown realm of concepts or ideas.

\section{Library Services in the United States}

UNDER tho title "Professional Library Iiducation" the Office of Education, United States Department of the Interior, has issued a bullotin by Nora $E$. Boust (Bull. No. 23; 1937) describing tho present position of library sorvices in the United States and indicating tho possibilities it offers as a carcer, and tho qualifications required for the various ficlds of service. Much that is said of the different types of library such as the public library, the school, the university or the special library is truo generally, and if duo allowance is mado for the different conditions and details in tho United States, this pamphlet gives a reasonably sound guido to tho possibilities in Great Britain also, oven if somo directions have beon much moro doveloped in the United States. Details regarding training for librarianship, like the figures showing tho present status of tho profession, relato solely to tho United States and at tention is directed to a marked growth in the number of librarians in the last threo decades, particularly in comparison with tho number of practitioners in other professions. Somo reasons for success and fuilure in library work which are set forth in conclusion aro of general validity.

\section{The Society of Applied Biologists}

PrIor to the year 1904 thero was no sciontific society or journal in the United Kingdom devoted to applied biology. There was, moreover, little opportunity or encouragement for rosearch in this field, and the work of the universitios and other 
educational institutions was primarily concerned with puro science. Owing to the initiative of Mr. W. E. Collinge of the University of Birmingham and others, however, the Society of Applied Biologists (as it is now termed) came into being. And as 1938 marked the publication of the twenty-fifth volume of its journal (Annals of Applied Biology), Prof. W. Brierley, joint editor since 1921, has written an interesting account of the development of the Association (Ann. App. Biol., 26, 178; 1939), correlating it with more general trends of development in the country over the same period of years. From the outset the Society has welcomed all investigators in economic biology, whether agricultural, horticultural, medical or commercial, and since its inception has steadily widened its interests. The journal, too, has increased in scientific value, developing from a volume of 359 pages in 1922 to one of 891 pages in 1938. The inclusion of photographs of the presidents of the Association from 1904 up to the present time adds much to the interest of the retrospect.

\section{Agricultural Research Institutes}

THE reports on the work of the agricultural researeh institutes in the United Kingdom carried out during the year ending September 1936 have now been published (London: H.M. Stationery Office. 5s.). The volume also includes reports of a number of other investigations, particularly into animal diseases, set afoot by the Agricultural Research Council, and accounts of the research activities of the agricultural advisory officers. Those who require fuller informa. tion on any subject are invited to consult the original papers, a list of which is attached to each report, or to inquire of the director of the institution concerned. Farmers and others in need of advice on agricultural or horticultural matters are reminded that by applying to the agricultural organizer for their county, they can draw direct benefit from these research and advisory services. It is perhaps unfortunate that so much delay occurs before these reports are published, as thereby some of their value is inevitably lost.

\section{"Know Your School" Movement in the United States}

To the various agencies which foster local interest in the public schools of the United States, such as the official popular magazine School Life and parents' associations, a notable addition has recently been made. At the request of the American Association of University Women, the Office of Education pre. pared a series of study outlines of certain aspects of the public school system for the use of the Associa. tion's branches. These proved so widely acceptable that they are being reprinted as ten-page leaflets. Those already issued are: "Know your Board of Education" (Local Education Authority), "Know your Superintendent", "Know your School Principal" and "Know your Teacher". They deal simply and clearly with such questions as "What are the duties of the principal ?", "What should be his qualifications ?", "Relationship to the local education authority, to the superintendent, to supervisors, to teachers, to the school janitor, to the community". They are well adapted for guiding discussion by study circles and contain suggestions for investigation and dis. cussion. In an article by the president of the University of Chicago which appeared in The Times United States Supplement of June 8, reference is made to "thedeep and abiding faith of the people in education", and it concludes-" "we shall yet make good our boast. that we are giving the world a demonstration of education by and for democracy". The leaflets should serve as an acid test of this faith, and eventually tend to strengthen it.

\section{Manufacture of Rare Gases}

IN an article by H. C. A. Holleman on the manufacture of rare gases (Philips Tech. Rev., Nay), a method is described by which rare gases, as well as oxygen and nitrogen are obtained from the air at the Philips' factories at Eindhoven in Holland. During the Great War, when it became more and more difficult to import the argon necessary for filling the incandescent lamps made in the factory, they were forced to manufacture the gas itself and a gas liquofaction plant was installed. This plant continued to grow steadily after the War, as it was found to supply many needs. So many different gases, all of which can be obtained from liquid air, are used in the Philips' factories that it was very important to have the whole manufacture under one control. Besides argon, which is used for filling electric lamps, the rare gases helium and neon are also used in gas discharge tubes. For glass blowing and in the machine shops large quantities of oxygen are used in order to reach higher combustion temperatures than it is possible to reach with air. Liquid oxygen and nitrogen are both used on a large scale for cooling purposes and as aids in obtaining a high vacuum.

As a protective gas in the working of metal parts for electric lamps and radio valves, much use is made of a mixture of nitrogen and hydrogen. Nitrogen is also used during the manufacture of electric lamps as a washing gas, while it is also used to fill special kinds of lamps. A modern installation for the separation of air by the Linde method is described. Since krypton and xenon have relatively high boiling points, they collect in the liquid container below the main column, which contains oxygen for the most part. Methane occurs in variable amounts in the air and has about the samo boiling point as krypton, so that it is collected with the krypton in the liquid oxygen. This leads to difficulties in practice since liquid oxygen together with a combustible substance like methane can easily form an explosive mixture and lead to accidents. Hence the strictest precautions have to be taken in the preparation of krypton and xenon.

\section{Earthquakes registered at De Bilt during 1936}

The "Seismische Registrierungen in De Bilt", 24 ; 1936, published in November 1938 and written by Dr. G. Van Dijk with a foreword by Dr. H. G. Cannegieter, contains a description of the instruments in uso at the station with the constants necessary for the interpretation of the seismograms obtained, a list of the abbroviations used, acknowledgments, a short 